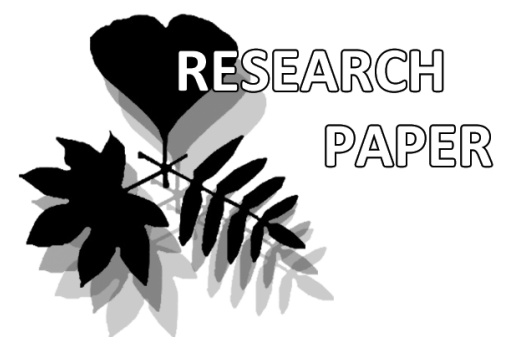

\title{
Vegetation dynamics at two mud volcanoes of Sakhalin Island (Russia): comparison of chronosequences
}

\author{
Kirill A. Korznikov
}

Kirill A. Korznikov

e-mail: korzkir@mail.ru

Botanical Garden-Institute FEB RAS Vladivostok, Russia

Manuscript received: 13.10.2017 Review completed: 15.11.2017

Accepted for publication: 21.11.2017

Published online: 24.11.2017

\begin{abstract}
A B S T R A C T
There are two actives mud volcanoes in the southern part of Sakhalin Island (Far East, Russia), which strongly influence the surrounding vegetation and generate new sites for primary successions. Vegetation dynamics and chemical properties of mud substrate at chronosequence gradient were investigated. I created 425 vegetation sampling quadrates $(1 \times 1 \mathrm{~m})$ in areas without forest vegetation and 24 plots $(10 \times 10 \mathrm{~m})$ in forest areas around volcanoes (a 'final' stage of succession). I determined $\mathrm{pH}$ and total dissolved solids from the mud substrate of each succession stage. NMDS was used to assess the direction of succession trajectories. Total dissolved solids and $\mathrm{pH}$ of mud substrate decrease; floristic richness, total plant cover, and $\alpha$-diversity of vegetation increase along the gradients of successions. At the final stage of succession, when the soil is no longer saline and has low $\mathrm{pH}$, the similarity of the vegetation cover can be attributed by common regional condition suitable for coniferous forests.
\end{abstract}

K e y w o r d s : mud volcanoes; primary succession; chronosequence; landscape context

\section{P E 3 Ю M E}

Корзников К.А. Аинамика растительности на Авух грязевых вулканах острова Сахалин (Россия): сравнение временных рядов. На юге острова Сахалин (Аальний Восток, Россия) расположены Ава грязевых вулкана. Их активность сильно влияет на окружающую растительность и формирует субстраты, на которых разворачивается процесс пионерной сукцессии. На градиентах сукцессий были исследованы динамика растительного покрова и изменение химических параметров грязевых суб́стратов. Я выполнил описания на 425 пробных площадках (1×1 м) в пределах зарастающих грязевых полей и на 24 пробных площаАях $(10 \times 10$ м) в окружающих вулканы месных сообществах («финальная» стаАия сукцессии). Я определил рН и общую минерализацию водных вытяжек из грязевого суббстрата. Многомерное неметрическое шкалирование было применено Аля непрямой ординации пробных площадок и определения траекторий сукцессий. На граАиентах сукцессий общая минерализация и рН субстрата уменьшаются, а флористическая насыщенность, общее проективное покрытие и $\alpha$-разнообразие растительных сообществ увеличиваются. На финальных стадиях сукцессий, когда субстрат перестает быть засоленным, и его рН становится низким, сходство растительного покрова Авух вулканов определяется региональными условиями, подАерживающими существова-

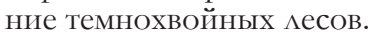

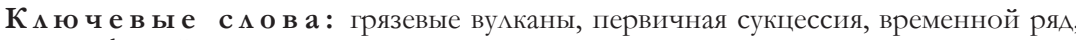
мандшафтный контекст
The development of vegetation succession depends on the regional pool of species, substrate conditions, biotic relationships, disturbance regime and landscape conditions (Walker \& del Moral 2003). One of the important problems for understanding the dynamics of vegetation cover is to determine the contribution of the environmental conditions for different types of vegetation at different stages of primary and secondary successions. This is also important for management decisions about vegetation and landscapes, and for the monitoring of restoration projects (Walker et al. 2007).

Landscape variables, collectively, the landscape context, local conditions, as well as the biotic relationships between organisms are now considered as factors that can influence succession. Landscape context includes climate, relief, surrounding vegetation, availability of diaspores, and anthropogenic stress (Benjamin et al. 2005, del Moral et al. 2005, Kirmeret al. 2008, Prach et al. 2014). The surrounding vegetation is an important part of the landscape context, since the local species pool determines the availability of diaspores and thereby influences succession (Zobel et al. 1998). The surrounding vegetation can be considered a target of succession. The concept of potential natural vegetation applies in this case (Prach et al. 2016).

A number of studies has shadowed light on natural primary successions in landscapes transformed during the 
eruptive activity of volcanoes and post-volcanic phenomena (Tsuyuzaki 1991, 2008, Burns 1997, del Moral \& Larcher 2005, Tsuyuzaki \& Hase 2005, del Moral 2007, 2009, Cutler et al. 2008). Pioneer successions in such landscapes are due to lava eruptions and the tephra deposition. Del Moral et al. (2005) have shown that often the formation of pioneer communities on volcanic sediments is a stochastic process associated with differences in the intake of diaspores and plant germination. The duration of successions on volcanic substrates in cold biomes extends hundreds of years (Grishin et al. 1997, Cutler et al. 2008, Korablev \& Neshataeva 2016). Climatic and landscape variables change over such a long period, making it impossible for the formation of vegetation that is completely analogous to that which was previously disturbed (Chiaruchii et al. 2010, Finsinger et al. 2017). The long duration of successions often leaves no other choice than considering the spatial vegetation change as temporal stages (Walker et al. 2010). Also, interpretation of the spatial series as proxies for succession is not always the right approach and can lead to distorted conclusions (Johnson \& Miyanishi 2008).

In contrast to the lavas and pyroclastic deposits of magmatic volcanoes, successions on mud volcanoes take place an order of magnitude faster. Together with the relatively small size of the mud fields, this makes mud volcanoes good places to study successions. I introduce here the results of a study carried out over 2013-2016 on two mud volcanoes located at a distance of $150 \mathrm{~km}$ from each other. The chemistry of mud substrates of mud volcanoes is similar, that is, they have identical local baseline conditions, but are located in different landscape. The vegetation of both volcanoes represents a reliable chronosequence: different plant communities represent different stages of pioneer

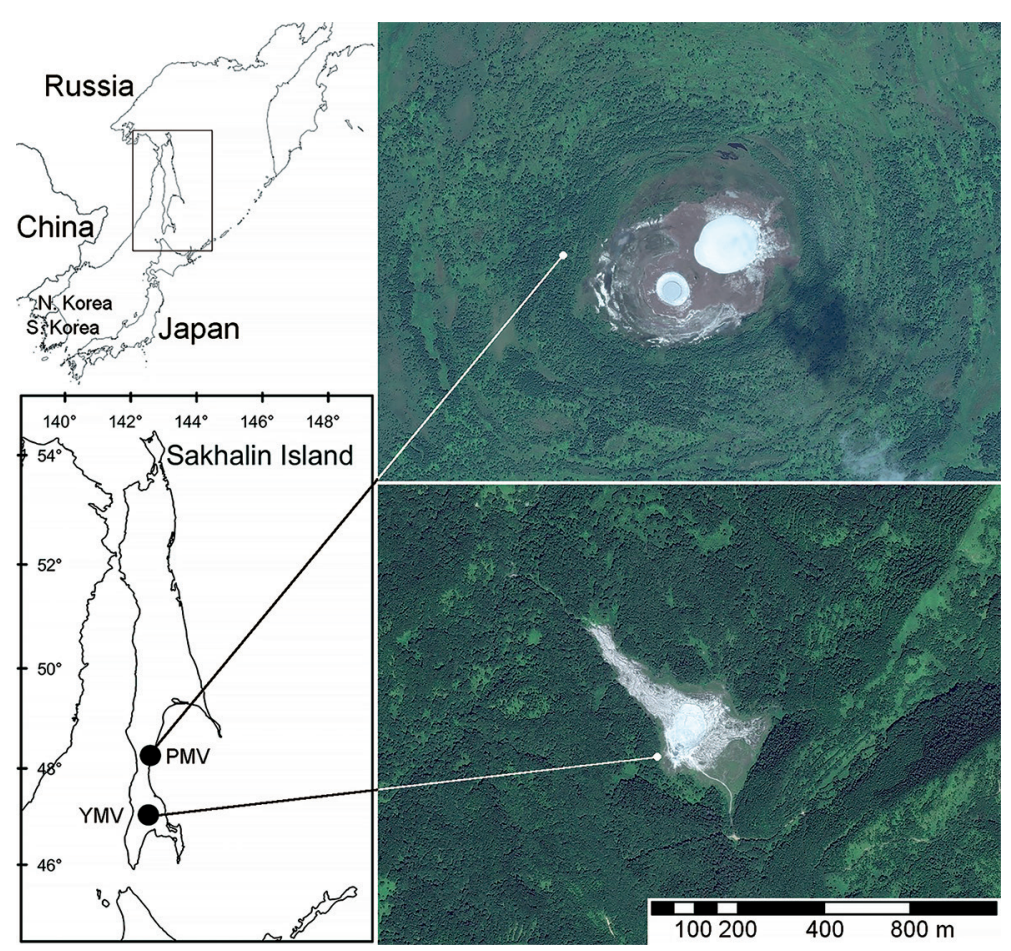

Figure 1 Locations of mud volcanoes. Image by Digital globe. From: https:// www.digitalglobe.com/ succession. The aim of this paper is demonstrated the advantage the landscape condition over local conditions in the courses of pioneer succession.

\section{MATERIAL AND METHODS}

\section{Study sites}

Magmatic volcanism and mud volcanism are not connected by a common genesis. Mud volcanoes throw a watered mud substrate onto the daylight surface. They are confined to oil and gas-bearing areas, including Sakhalin Island (Kopf 2002). The erupted mud substrate has a high $\mathrm{pH}$ and is highly saline, which leads to the formation of specific ecotopes (Korzhenevsky \& Klyukin 1991, Ting \& Poulsen 2009). Like with magmatic volcanoes, periods of intense activity alternate with periods of dormancy, and primary succession begins on pioneer substrates. Mud volcano areas are much smaller than those of magmatic volcanoes.

Studies were carried out on two mud volcanoes located in the south of Sakhalin Island, Russia (Fig. 1). The Yuzhno-Sakhalinsk mud volcano (YMV) is located in the vicinity of the city of Yuzhno-Sakhalinsk. A 7.5 hectare area of its modern mud fields has no forest vegetation. The volcano is located on the slope of a hill that stretches out to the northwest along the gradient of the slope. The maximum height, $300 \mathrm{~m}$ a.s.l., corresponds with the center of the volcano. The minimum height, $270 \mathrm{~m}$ a.s.l., is at the extreme northernmost point of the mud field.

The actual dates of the last strong eruptions of the volcano are known: 1959, 1979, and 2001. These eruptions have contours, captured with the help of GPS in aerial photographs and visual observations (Prytkov et al. 2014). At the beginning of the 20th century there was another active volcano southwest from the modern volcano, but with a fading activity (Isidzaki 1929, Mel'nikov \& Sabirov 1999). Now this eruption center is inactive. Forest communities are formed on its deposits. According to estimates and examination of the substrate, the total area of the mud volcano deposits is at least 20 hectares, with forest vegetation on the older erupted substrate around the edge of the modern mud fields.

The Pugachevo mud volcanoes group (PMV) is located at the bottom of a shallow basin. The PMV consists of a central volcano, Maguntan, and two small satellite volcanoes. The Maguntan mud fields occupy about 24 hectares. The satellite volcanoes occupy about 0.5 hectares each. These volcanoes are smaller and less active copies of the Maguntan volcano, located $500 \mathrm{~m}$ to its south and $500 \mathrm{~m}$ to its north. In addition of being smaller, they have weaker activity (Mel'nikov 2011). The height of the central part of the Maguntan mud volcano is $56 \mathrm{~m}$ a.s.l.; the height of its outskirts is $54 \mathrm{~m}$ a.s.l. The mud fields are round in shape. It is known that there were two particularly strong eruptions in 1938 and 2005, as well as a number of weaker ones. With the exception of the last strong eruption in 2005, the exact contours of 
the eruptions are unknown since the available aerial photographs and satellite images have insufficient resolution. The 2005 eruption turned out to be the largest and most unusual, as two eruptive centers were active at once (Ueda 1938, Siryk 1970, Ershov \& Mel'nikov 2007, Mel'nikov 2011; noticeable in Fig. 1).

According to the data obtained from nearest weather stations (19 km to the southeast for the YMV and $42 \mathrm{~km}$ to the north for the PMV) mean annual temperature for the $\mathrm{YMV}$ is $+2.4^{\circ} \mathrm{C}$; in the PMV is $+1.7^{\circ} \mathrm{C}$. The mean annual precipitation in the YMV is $866 \mathrm{~mm}$; in the PMV is 838 $\mathrm{mm}$. The Köppen-Geiger climate classification for this climate is "Dfb" - humid continental climate with warm summer (Peel et al. 2007). According to Nakamura et al. (2007) the type of macrobioclimat is marine boreal.

\section{Collecting vegetation and soil chemistry data}

I created vegetation sampling quadrates $(1 \times 1 \mathrm{~m})$ in a random manner for plant communities of mud volcanoes in 2013-2014. In total, there were established 425 such plots: 278 on PMV and 147 on YMV. I created quadrate sampling plots of about $100 \mathrm{~m}^{2}$ for late succession forest sites in 2016: 11 on the PMV and 13 on the YMV. The coordinates of each plot were recorded using GPS Garmin e'Trex 30. Phytosociological relevés (vegetation descriptions) were recorded in all plots. Vascular plant cover was determined through visual observation, then translated according to the ordinal scale: 7 - cover of more than $51 \% ; 6-26-50 \%$; $5-11-25 \%$; $4-6-10 \% ; 3-1-5 \% ; 2-<1 \% ; 1-<0.1 \%$.

Substrate was sampled at 0 to $10 \mathrm{~cm}$ depth on four randomly selected spots within each succession stage. Additionally, I took 6 soil samples from a deeper layer $(0-30 \mathrm{~cm})$ of forest soil in forest sites. A total of 26 substrate and soil samples were selected. I determined $\mathrm{pH}$ and total dissolved solids (TDS) in saturated paste (1:5 dilutions). TDS and $\mathrm{pH}$ were measured by tester (Hanna HI 98130 Combo).

\section{Data analysis}

Since the contours of the mud fields that appeared in 1959, 1979, and 2001 are known for the YMV, I considered the plant communities on them as stages of succession. I recognized forest communities on the substrates of old undated eruptions, which is the 'final' stage of succession as close to potential natural vegetation.

For the PMV, their eruption contours are unknown. Here I used TWINSPAN (PC-ORD 5.0) to clustering homogeneous groups of vegetation (McCune \& Grace 2002). The result was eight clusters of relevés, which I considered as vegetation communities forming a chronosequence (Walker et al. 2010). These plant communities gradually replace each other as they move away from the center of the volcano and approach its periphery (Korznikov 2015). Focusing at the different remoteness of communities from the center of the volcano, I also divided them into three stages of succession. These stages are easily differentiated visually and, judging by analogy with the YMV, clearly belong to mud fields of different ages. I considered the fourth 'final' stage such as forest potential natural vegetation.

The statistical processing was performed in the $\mathrm{R}$ ( $\mathrm{R}$ core team 2014) with the 'vegan' package (Oksanen et al. 2017). I calculated species richness ( $\alpha$ diversity), plant cover, and Shannon's diversity per plots. For calculating differences between the number of species, plant cover, and diversity in succession stages, I used the Mann-Whitney U-test, because some data were not normally distributed (according to Shapiro-Wilk's test for normality, $\mathrm{p}<0.05$ ). As a part of multidimensional analysis procedure, I applied non-metric multidimensional scaling (NMDS, metaMDS function) to the vegetation data. NMDS was ran with the Bray-Curtis distance measure comparing the similarity in the vascular plants species composition of all plots and taking into account the abundance of species with ordinal scale. Twodimension solution was used with rescaling to half-change units. I subjected the best NMDS-solution (stress 0.11) by multidimensional rotation using MDS rotate function, so that its first axisbecame parallel to the index number of volcanoes (1 - PMV, 2 - YMV). The coordinates of the succession stages centroids were calculated and connected by arrows to show the trajectories on a biplot.

Botanic nomenclatures for vascular plants are given according to Czerepanov (1995), except for Picea, which follows Farjon (1990); for mosses - according to Ignatov et al. (2006).

\section{RESULTS}

In the course of succession, floristic richness, total plant cover, and $\alpha$-diversity increase (Fig. 2). This growth corresponds with a change in the chemistry of the substrate: a decrease in TDS and pH (Table 1). Frequency of main vascular species in different successional stage of both volcanoes is given in Table 2.

Local endemic plant species characterize early stages of succession on the PMV. Specific taxa were found by Japanese botanists in the first half of the last century (Sugawara 1940). At the PMV, plant communities of the first stages of successions consist of a number of local endemic taxaDeschampsia tzvelevii, Primula sachalinensis, Gentianella sugawarae, Artemisia limosa, with wet microsites being characterized by the presence of Triglochin palustre (Fig. 3). Communities of the second stage of succession consist of dwarf willow shrubs (Salix fuscescens) and green mosses with dominance of Campylium stellatum, with wet microsites being occupied by Eleocharis kamtschatica. At the third stage, thickets of Hedysarum sachalinense are formed in mesic sites, with Calamagrostis neglecta being found in conditions of abundant

Table 1. Chemical properties of substrate samples

\begin{tabular}{lccccc}
\hline Volcano & Stage & $\mathbf{n}$ & $\mathbf{p H}$ & TDS, \%o & $\begin{array}{c}\text { Soil } \\
\text { depth, } \\
\mathbf{c m}\end{array}$ \\
\hline \multirow{3}{*}{ YMV } & I & 4 & $8.6 \pm 0.2$ & $7.4 \pm 0.1$ & 0 \\
& II & 4 & $8.2 \pm 0.2$ & $3.6 \pm 1.2$ & $0^{*}$ \\
& III & 4 & $7.8 \pm 0.3$ & $1.9 \pm 0.2$ & $\sim 1$ \\
PMV & IV & 6 & $4.3 \pm 0.1$ & $0^{* *}$ & $\sim 10$ \\
& I & 4 & $9.3 \pm 0.1$ & $5.2 \pm 0.9$ & 0 \\
& II & 4 & $8.4 \pm 0.2$ & $4.1 \pm 0.4$ & $0^{*}$ \\
& III & 4 & $7.2 \pm 0.4$ & $1.9 \pm 0.1$ & $\sim 1$ \\
& IV & 6 & $4.5 \pm 0.1$ & $0 * *$ & $\sim 10$ \\
\hline
\end{tabular}

* Only plants litters present

** Subsoil mud substrate has a weak salinity 

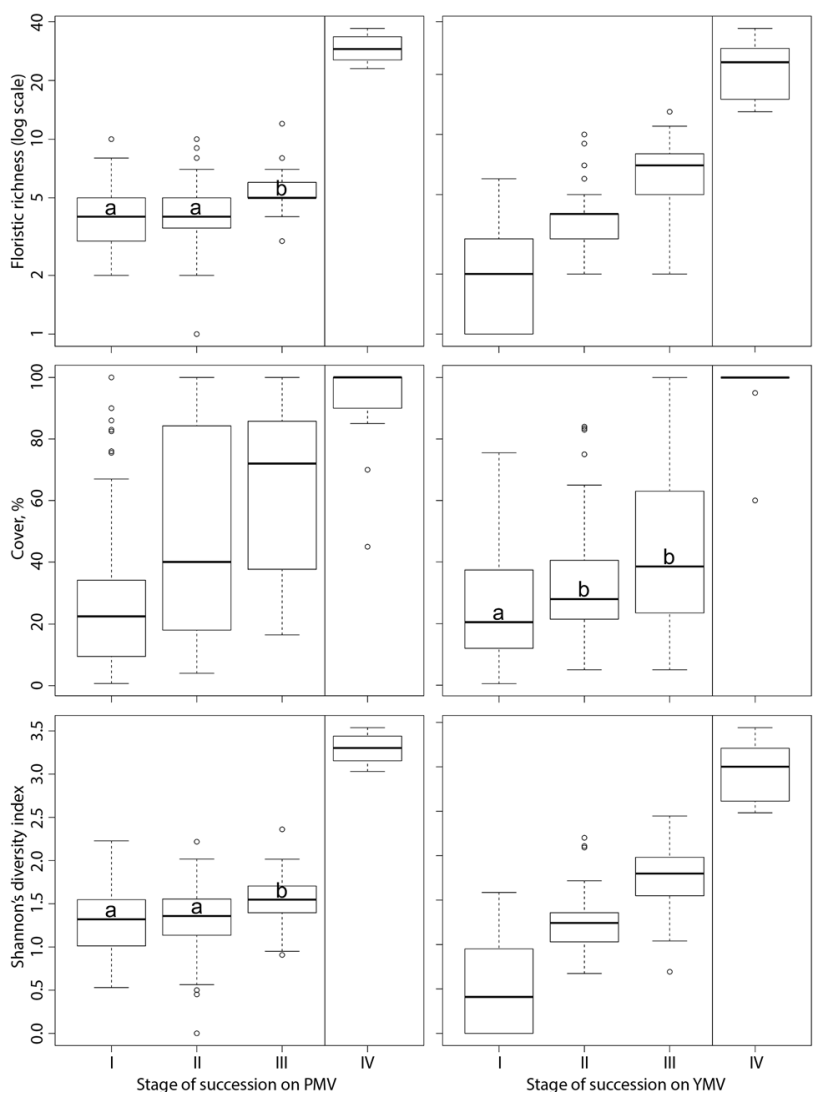

Figure 2 Change of floristic richness, vascular plant cover and Shannon's diversity follow the chronosequence. Left diagrams - the PMV, right - the YMV. Different letters indicate significant difference between medians $(\mathrm{p}<0.01)$

moisture. Alien species are completely absent on the lessaccessible the PMV. Wet larch forests (Larix cajanderi) and partial Sakhalin fir (Abies sachalinensis) and Jezo spruce (Picea jezoensis) are growing on old mud deposits (Table 1). There are not even approximate data on the succession rate on the PMV or the time, during which the succession reaches the stage of the community of the larch forest. Apparently, reaching the forest vegetation stage takes a little longer on the PMV. The average age of larch on the edge of the mud field is 80 years.

At the YMV Triglochin palustre community is formed in the first stage of succession. Ravines are actively forming on the mud field generated after the 2001 eruption. I did not record differences in the vegetation cover at the bottom of the ravines and beyond the ravines, as it was demonstrated for tephra deposits on magmatic volcanoes in Japan (Tsuyuzaki 2009). In the second stage, the main species is Phragmites australis.

Due to its convenient location and the availability of roads, the YMV is a popular tourist destination. Together with a large number of tourists and the associated trampling impact, visitors have brought non native species including Pilosella aurantiaca, Plantago major, Taraxacum officinale, and Tussilago farfara.

In the third stage, Phragmites australis remains dominant, but willow-shrub (Salix udensis), Abies sachalinensis and Alnus birsuta young trees appear. Forest vegetation on the old mud fields of the YMV contains communities of Abies sachali-
Table 2 Main vascular plant species frequent in different stage of succession. Values are percentage constancy. Asterisk* indicates dominants. Constancy above $80 \%$ shaded

\begin{tabular}{|c|c|c|c|c|c|c|c|c|}
\hline \multirow{2}{*}{$\begin{array}{l}\text { Location } \\
\text { Number of relevés }\end{array}$} & \multicolumn{3}{|c|}{ PMV fields } & \multicolumn{3}{|c|}{ YMV fields } & \multicolumn{2}{|c|}{$\sum_{0}^{0} 0$} \\
\hline & 111 & 80 & 87 & 44 & 41 & 62 & 11 & 13 \\
\hline Stage of succession & $\mathrm{I}$ & II & III & I & II & III & IV & IV \\
\hline \multicolumn{9}{|c|}{ species frequent of the PMV } \\
\hline Primula sachalinensis* & 82 & 20 & 3 & $\cdot$ & · & · & $\cdot$ & - \\
\hline Deschampsia trvelevii* & 67 & 15 & 1 & . & $\cdot$ & $\cdot$ & $\cdot$ & - \\
\hline Allium maximowiczii & 60 & 40 & 26 & . & . & . & $\cdot$ & . \\
\hline Gentianella sugawarae & 51 & 8 & 18 & $\cdot$ & $\cdot$ & $\cdot$ & $\cdot$ & - \\
\hline Salix fuscescens* & 18 & 73 & 92 & . & $\cdot$ & $\cdot$ & 27 & - \\
\hline Hedysarum sachalinense* & 1 & 18 & 56 & . & . & . & 18 & • \\
\hline Calamagrostis neglecta* & 1 & 5 & 45 & $\cdot$ & . & $\cdot$ & $\cdot$ & . \\
\hline \multicolumn{9}{|c|}{ species frequent of the YMV } \\
\hline Taraxacum officinale & · & · & - & 18 & 39 & 47 & $\cdot$ & 15 \\
\hline Aster glebnii & · & 1 & - & 9 & 51 & 69 & 27 & 46 \\
\hline Senecio cannabifolius* & . & $\cdot$ & . & 5 & 32 & 50 & 9 & 46 \\
\hline Picris japonica & · & · & · & $\cdot$ & 32 & 61 & $\cdot$ & $\cdot$ \\
\hline Salix caprea & . & . & . & $\cdot$ & 29 & 47 & $\cdot$ & 54 \\
\hline Pilosella aurantiaca & · & · & · & 9 & 34 & 45 & · & \\
\hline \multicolumn{9}{|c|}{ species frequent of both volcanoes } \\
\hline Triglochin palustre* & 68 & 40 & 21 & 98 & $\cdot$ & $\cdot$ & $\cdot$ & $\cdot$ \\
\hline Phragmites australis* & $\cdot$ & 39 & 22 & 50 & 100 & 97 & 64 & 23 \\
\hline \multicolumn{9}{|c|}{ species frequent of forest communities } \\
\hline Larix cajanderi* & $\cdot$ & 10 & 10 & $\cdot$ & $\cdot$ & 6 & 100 & 8 \\
\hline Rosa amblyotis & . & $\cdot$ & $\cdot$ & . & . & 6 & 100 & 8 \\
\hline Lilium debile & . & . & . & . & . & $\cdot$ & 100 & 15 \\
\hline Abies sachalinensis* & . & . & . & . & . & 8 & 100 & 54 \\
\hline Alnus birsuta* & . & $\cdot$ & $\cdot$ & . & . & 6 & 91 & 69 \\
\hline Cirsium kamtschaticum & . & 13 & 16 & . & 5 & 11 & 91 & 69 \\
\hline Maianthemum dilatatum & . & $\cdot$ & $\cdot$ & . & . & . & 91 & 38 \\
\hline Calamagrostis langsdorffii & · & · & · & · & . & . & 91 & 23 \\
\hline Angelica genuflexa & . & . & . & . & . & $\cdot$ & 82 & 46 \\
\hline Trientalis europaea & · & - & . & . & $\cdot$ & $\cdot$ & 82 & 15 \\
\hline Clintonia udensis & · & . & - & . & . & · & 82 & 15 \\
\hline Trillium camschatcense & . & . & $\cdot$ & . & . & . & 73 & 31 \\
\hline Carex cespitosa & · & 16 & 14 & . & . & · & 73 & . \\
\hline Sorbus commixta & . & $\cdot$ & $\cdot$ & $\cdot$ & $\cdot$ & 6 & 73 & 46 \\
\hline Sanguisorba tenuifolia & . & 6 & 44 & . & . & . & 64 & \\
\hline Vaccinium ovalifolium & . & . & $\cdot$ & . & . & . & 64 & 15 \\
\hline Cimicifuga simplex & . & $\cdot$ & $\cdot$ & . & $\cdot$ & . & 36 & 77 \\
\hline Cacalia robusta & - & $\cdot$ & $\cdot$ & - & $\cdot$ & $\cdot$ & $\cdot$ & 85 \\
\hline Filipendula camtschatica* & · & · & · & · & 5 & 18 & 45 & 77 \\
\hline Euonymus miniata & . & . & . & . & . & $\cdot$ & 64 & 62 \\
\hline Picea jesoensis* & . & 1 & . & . & . & 13 & 36 & 46 \\
\hline
\end{tabular}

nensis and Picea jezoensis. Counting the annual rings of fir and spruce in the vicinity of the YMV allows to determine the time, at which the forest vegetation appeared about 100 years after the eruption (Mel'nikov \& Sabirov 1999, my unpublished data). It should be noted that in the plant community on the 1959 mud substrate there is already a young trees of Abies sachalinensis and Picea jezoensis, but apparently before formation the closed community will pass by the stage of the dominance of deciduous species such as $\mathrm{Al}$ nus hirsuta. Now the community of Alnus hirsuta with the participation of dark-coniferous species occupies a mud substrate dating roughly since 1930s (Mel'nikov \& Sabirov 1999). Succession on substrates of mud volcanoes passes faster than on anthropogenic substrates and the deposits of magmatic volcanoes.

The results of NMDS show the separation of scattering clouds along the first axis, which is due to the location on the PMV or the YMV (Fig. 4). The second NMDS axis is associated with gradient of the primary succession. The successions trajectories that connect the centroids of different 

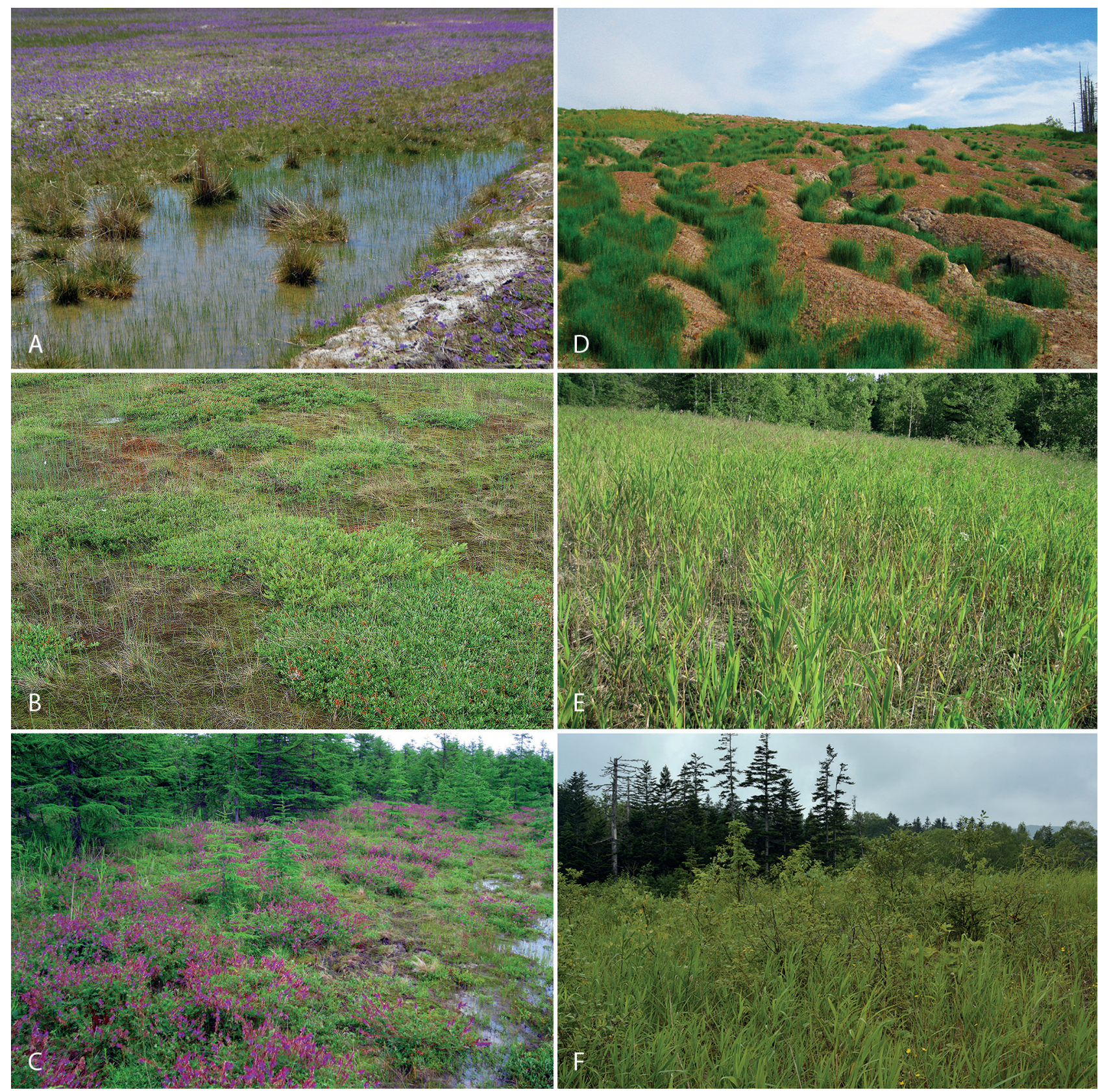

Figure 3 Successional stages of vegetation at mud fields. A-C: Pugachevo mud volcanoes group, stages I (A), II (B) and III (C); D-F: Yuzhno-Sakhalinsk mud volcano, stages I (D), II (E) and III (F)

succession stages show differences in the early and middle stages in comparison with the pioneer stage, but they to converge in the fourth forest stage. Results of NMDS and Bray-Curtis dissimilarity show significant differences in the composition of the seral vegetation on the PMV and the YMV. The first stages of succession on mud volcanoes are closer to each other than the second and third. The convergence of communities occurs only at the final stages approaching PNV. Although forest communities belong to different forest associations, their similarity is stronger than the similarity between the seral stages.

\section{DISCUSSION}

The specific character of local conditions on mud volcanoes consists of a strong salinity and a high $\mathrm{pH}$, which act as an abiotic filter (Belyea \& Lancaster 1999, Prach et al. 2015b). On the other hand, since the products of eruption of the two mud volcanoes studied here are chemically almost identical, the differences in the composition of the pioneer plant communities are explained by different landscape contexts. The sloped location of the YMV leads to repeated disturbances of the same sites due to the predominant distribution of mud flows in direction down the slope. This, in all likelihood, leads to the periodic complete destruction of the vegetation cover of the volcano after catastrophic eruptions. The features of the flat terrain of the PMV make possible the permanent presence of differently aged mud fields and micro-refugia on which plants are preserved even in the case of very strong eruptions. Perhaps that's why, unlike the YMV, local endemic taxa formed on 

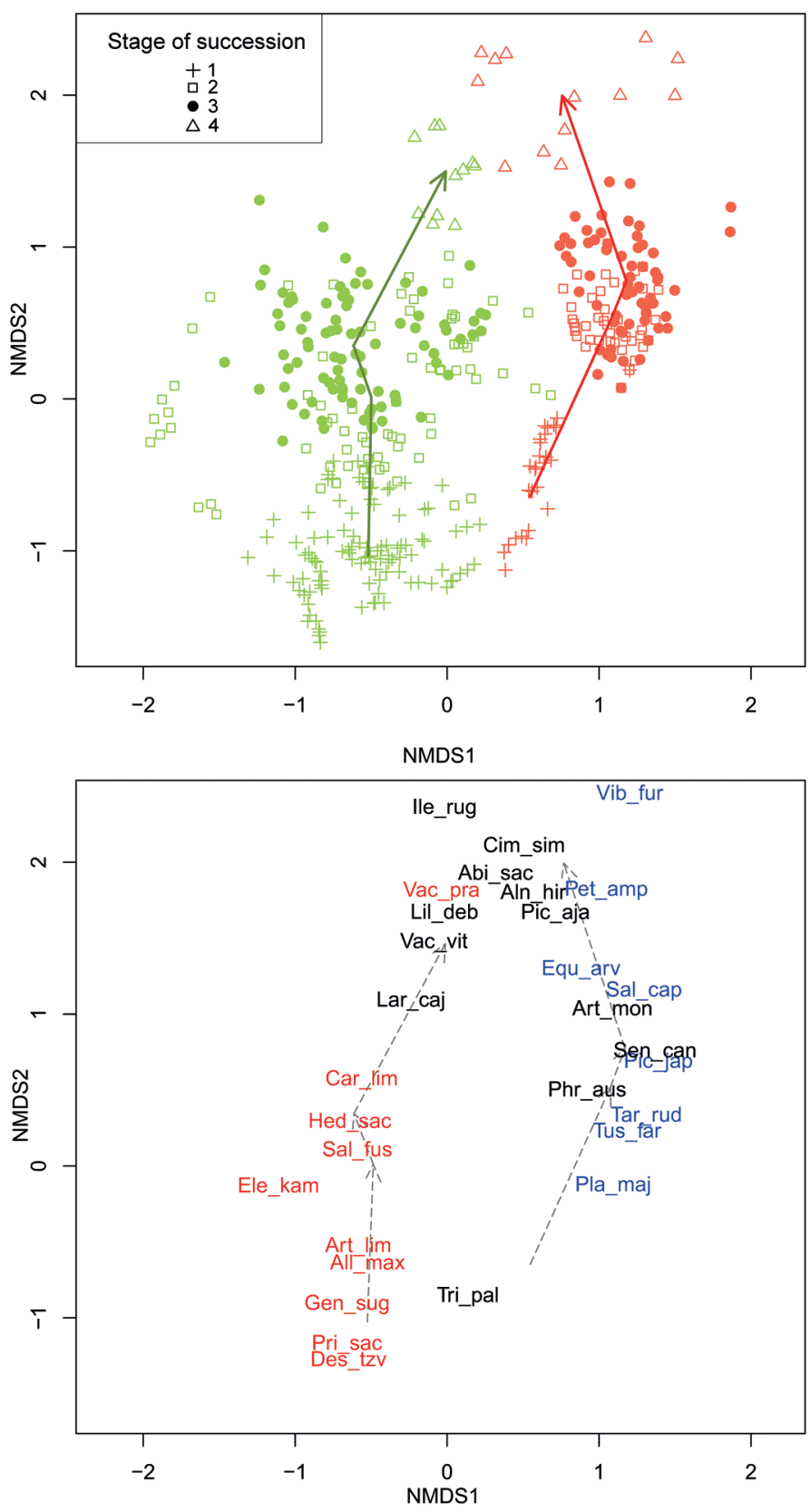

Figure 4 NMDS ordination: a) relevés; green marks indicate PMV, red YMV; b) species; color texts indicate species association with volcanoes: red - PMV, blue - YMV, black - both. Species abbreviations: Abi sac Abies sachalinensis, All_max - Allium maximowiczii, Aln_hir - Alnus birsuta, Art_lim - Artemisia limosa, Car_lim - Carex limosa, Cim_sim - Cimicifuga simplex, Des_tzv - Deschampsia tzvelevii, Ele_kam - Eleocharis kamtschatica, Equ_arv - Equisetum arvense, Gen_sug - Gentianella sugawarae, Hed_sac Hedysarum sachalinense, Ile_rug - Ilex rugosa, Lar_caj - Larix cajanderi, Lil_ deb - Lilium debile, Pet_aml - Petasites amplus, Pic_jez - Picea jezoensis, Pic_ jap - Picris japonica, Phr_aus - Phragmites australis, Pla_maj - Plantago major, Pri_sac - Primula sachalinensis, Sal_cap - Salix caprea, Sal_fus - Salix fuscescens, Tar_off - Taraxacum officinale agg., Tri_pal - Triglochin palustre. Tus_far - Tussilago farfara, Vac_pra - Vaccinium praestans, Vac_vit - Vaccinium vitisidaea, Vib_fur - Viburnum furcatum

the PMV. Flat terrain and good water-resistant properties determine the formation of microsites with standing water, which leads to the formation of more complex vegetation that is a typical example of a positive relationship between heterogeneous local conditions and biological diversity. On the YMV, the sloped landscape does not allow the forma- tion of microsites with differing levels of moisture. Thus, the relief affects local conditions, and through them on the vegetation cover.

The surrounding vegetation is a source of seeds entering the young mud fields of volcanoes. The seeds intake factor in some cases may be more important than local conditions (Salonen \& Setala 1992). Nevertheless, the specific local conditions of the mud fields are an abiotic filter and not all species from the surrounding communities can overcome it. The anthropogenic impact on such habitats is a serious factor in changes in their vegetation cover and how the species pools form, in connection with natural factors (Clarkson \& Clarkson 1983, Burns et al. 2013).

The increase in floristic richness, total plant cover, and $\alpha$-diversity has been repeatedly shown for successions in volcanic landscapes (del Moral \& Lacher 2005, del Moral et al. 2005, Tsuyuzaki \& Hase 2005, Tsuyuzaki 2009). On mud volcanoes, the increase in these features occurs after a decrease in unfavorable conditions for plants: after salts that are toxic for plants are washed out and the $\mathrm{pH}$ of the substrate goes down. Similar conclusions were reached earlier by Ivanov et al. (1989) having studied the process of soil formation on Crimean mud volcanoes.

The succession on the mud volcanoes is heading towards potential natural vegetation, which in the south of Sakhalin Island is represented by Abies sachalinensis and Picea jezoensis forests (Krestov \& Nakamura 2002). In the old mud fields of the YMV, the Alnus hirsuta forest community has already formed, similar in composition to the azonal plant communities of river valleys.

The concept of potential natural vegetation recently has been criticized (Chiarucci 2010). However, the potential natural vegetation concept is used successfully in studies of the succession targets in technogenic landscapes (Prach et al. 2016), and even more so for regions whose vegetation does not have a centuries-old history of anthropogenic transformation.

Prach et al. (2014) experimentally showed contribution decreasing of local conditions and increasing of the landscape context during succession. Although the chemical conditions acts identically on both volcanoes, it does not lead to the formation of the same communities. Lanta \& Leps (2009) hold the view that the differential survival of species under similar conditions is a factor determining the difference in succession.

The results of my work are consistent with the conclusions of Prach et al. (2014): convergence and divergence of plant communities occur depending on local and landscape conditions, and in general vegetation in the vicinity of disturbed sites. The landscape context is very important predictors for vegetation primary succession (Prach et al. 2015a, 2015b). Significant convergences of the composition of communities occur at the final stage of successions. Thus, although two mud volcanoes represent one geological phenomenon, ecotopes with chemically similar substrates and succession scenarios arise as a result of their eruptive activity, but a different land- 
scape conditions determines a strong dissimilarity of plant communities. The greatest similarity between vegetation on the volcanoes' deposits occurs at the very last stages, when the climatic variables determining the formation of zonal communities begin to dominate over the variables of local conditions.

\section{ACKNOWLEDGEMENTS}

I am grateful to Dmitry Kislov (Botanical Garden-Institute FEB RAS) and my colleagues from Department of Geobotany, Faculty of Biology of Lomonosov Moscow State University for making a number of critical comments and help in my work. I also gratefully acknowledge to Sara Moore for her assistance in text translation and editing.

\section{LITERATURE CITED}

Belyea, L.R. \& J. Lancaster 1999. Assembly rules within a contingent ecology. Oikos 86(3):402-416.

Benjamin, K., G. Domon \& A. Bouchard 2005. Vegetation composition and succession of abandoned farmed: effect of ecological, historical and spatial factors. Landscape Ecology 20(6):627-647.

Burns, B. 1997. Vegetation change along a geothermal stress gradient at the Te Kopia steamfield. Journal of the Royal Society of New Zealand 27(2):279-294.

Burns, B.R., J. Ward \& T.M. Downs 2013. Trampling impacts on thermotolerant vegetation of geothermal areas in New Zealand. Environmental Management 52(6):1463-1473.

Chiarucci, A., M.B. Araújo, G. Decocq, C. Beierkuhnlein \& J.M. Fernández-Palacios 2010. The concept of potential natural vegetation: an epitaph? Journal of Vegetation Science 21(6):1172-1178.

Clarkson, B.R. \& B.D. Clarkson 1983. Mt Tarawera: 2. Rates of change in the vegetation and flora of the high domes. New Zealand Journal of Ecology 6:107-119.

Cutler, N.A., L.R. Belyea \& A.J. Dugmore 2008. Spatial patterns of microsite colonisation on two young lava flows on Mount Hekla, Iceland. Journal of Vegetation Science 19(2):277-286.

Czerepanov, S.K. 1995. Vascular plants of Russia and adjacent states (the former USSR). Cambridge University Press, New York, 523 pp.

del Moral, R. 2007. Vegetation dynamics in space and time: an example from Mount St. Helens. Journal of Vegetation Science 18(4):479-488.

del Moral, R. 2009. Increasing deterministic control of primary succession on Mount St. Helens, Washington. Journal of Vegetation Science 20(6):1145-1154.

del Moral, R. \& L.L. Lacher 2005. Vegetation patterns 25 years after the eruption of Mount St. Helens, Washington, US. American Journal of Botany 92(12):1948-1956.

del Moral, R., D.M. Wood \& J.H. Titus 2005. Proximity microsites and biotic interactions during early primary succession. In: Ecological responses to the 1980 eruption of Mount St. Helens (V.H. Dale, F.J. Swanson \& C.M. Crisafulli, eds.), pp. 98-109, Springer, New York.

Ershov, V.V. \& O.A. Mel'nikov 2007. Unusual eruption of the Main Pugachevo gas-water-lithoclastic (mud) volcano in Sakhalin during the winter of 2005. Russian Journal of Pacific Geology 1(4):366-370.

Farjon, A. 1990. Pinaceae: drawings and descriptions of the genera: Abies, Cedrus, Pseudolarix, Keteleeria, Nothotsuga, Tsuga, Cathaya, Pseudotsuga, Larix and Picea. Koeltz Scientific Books, Koenigstein, 330 pp.
Finsinger, W., T. Giesecke, S. Brewer \& M. Leydet 2017. Emergence patterns of novelty in European vegetation assemblages over the past 15000 years. Ecology Letters 20(3):336-346.

Grishin, S.Yu., R. del Moral, P.V. Krestov \& V.P. Verkholat 1996. Succession following the catastrophic eruption of Ksudach volcano (Kamchatka, 1907). Vegetatio 127(2): 129-153.

Ignatov, M.S., O.M. Afonina, E.A. Ignatova, A. Abolina, T.V. Akatova, E.Z. Baisheva, L.V. Bardunov, E.A. Baryakina, O.A. Belkina, A.G. Bezgodov, et al. 2006. Checklist of mosses of East Europe and North Asia. Arctoa 15:1-130.

Isidzaki, M. 1937. Report on geological study of the Mototomari vicinty. SakhKNII AN SSSR, Yuzhno-Sakhalinsk, 16 pp. (in Russian and Japanese). [Исилзаки M. 1937. Отчет о геологическом исследовании района Мототомари. Южно-Сахалинск: СахКНИИ АН СССР. 16 с.].

Ivanov, V.F., E.F. Molchanov \& V.V. Korzhenevskiy 1989. Vegetation and soil formation on eruptions of mud volcanoes in the Crimea. Soviet Soil Science 21(4):11-18.

Johnson, E.A. \& K. Miyanishi 2008. Testing the assumptions of chronosequences in succession. Ecology Letters 11(5):419-431.

Kirmer, A., S. Tischew, W.A. Ozinga, M. von Lampe, A. Baasch \& J.M. van Groenendael 2008. Importance of regional species pools and functional traits in colonization processes: predicting re-colonization after largescale destruction of ecosystems. Journal of Applied Ecology 45(5):1523-1530.

Kopf, A.J. 2002. Significance of mud volcanism. Reviews of Geophysics 40(2):1-52.

Korablev, A.P. \& V.Y. Neshataeva 2016. Primary plant successions of forest belt vegetation on the Tolbachinskii Dol volcanic plateau (Kamchatka). Biology Bulletin 43(4):307-317.

Korzhenevsky, V.V. \& A.A. Klyukin 1991. Vegetation description of mud volcanoes of Crimea. Feddes Repertorium 102(1-2):137-150.

Korznikov, K. 2015. Vegetation cover at the Maguntan mud volcano (Sakhalin Island, Russia): species composition and spatial distribution. Phytocoenologia 45(1-2):125-134.

Krestov, P.V. \& Yu. Nakamura 2002. Phytosociological study of the Picea jezoensis forests of the Far East. Folia Geobotanica 37(4):441-473.

McCune, B. \& J.B. Grace 2002. Analysis of ecological communities. MjM Software Design, Glenenden Beach, Oregon.

Mel'nikov, O.A. 2011. On the dynamics and origin of the Pugachevo group of gas-water-lithoclast ("mud") volcanoes on Sakhalin Island: visual observations and orohydrography. Journal of Volcanology and Seismology 5(6):409-420.

Mel'nikov, O.A. \& R.N. Sabirov 1999. New data on the modern state and past activity of the South Sakhalin gas-water-mud volcano, Sakhalin Island. Tikhookeanskaya geologiya 18(3):37-46 (in Russian with English summary). [Мемьников О.А., Сабиров Р.Н. 1999. Новые Аанные о современном состоянии и былой активности Южно-Сахалинского газоводогрязевого вулкана (о. Сахалин) // Тихоокеанская геология. Т. 18, № 3. С. 37-46].

Nakamura, Yu., P.V. Krestov \& A.M. Omelko 2007. Bioclimate and zonal vegetation in Northeast Asia: first approximation to an integrated study. Phytocoenologia 37(34):443-470.

Oksanen, J., F.G. Blanchet, R. Kindt, et al. 2017. Vegan: community ecology package. $\mathrm{R}$ package version 2.4-3.https:// cran.r-project.org/web/packages/vegan/vegan.pdf. Last accesed 3 October 2017. 
Peel, M.C., B.L. Finlayson \& T.A. McMahon 2007. Updated world map of the Köppen-Geiger climate classification. Hydrology and Earth System Sciences 11:1633-1644.

Prach, K., K. Fajmon, I. Jongepierová \& K. Řehounková 2015a. Landscape context in colonization of restorted dry grassland by target species. Applied Vegetation Science 18(2):181-189.

Prach, K., P. Karešová, A. Jírová, H. Dvořáková, P. Konvalinková \& K. Rehounková 2015b. Do not neglect surroundings in restoration of disturbed sites. Restoration Ecology 23(3):310-314.

Prach, K., P. Pyšek \& K. Řehounková 2014. Role of substrate and landscape context in early succession: An experimental approach. Perspectives in Plant Ecology 16(4):174-179.

Prach, K., L. Tichý, K. Lencová, et al. 2016. Does succession run towards potential natural vegetation? An analysis across seres. Journal of Vegetation Science 27(3):515-523.

Prytkov, A.S., N.F. Vasilenko \& V.V. Ershov 2014. Simulation of the 2011 South Sakhalin mud volcano eruption based on the GPS data. Russian Journal of Pacific Geology 8(3):224-231.

R Core Team 2014. R: A language and environment for statistical computing. R Foundation for Statistical Computing. Vienna, Austria. http://www.R-project.org/. Last accesed 3 October 2017.

Salonen, V. \& H. Setala 1992. Plant colonization of bare peat surface - relative importance of seed availability and soil. Ecography 15(2):199-204.

Siryk, I.M. 1970. Mud volcanoes. In: Geologiya SSSR. Ostrov Sakhalin. Vol. 33. (V.N. Vereshchagin \& Yu.V. Kovtunovich, eds.), pp. 355-368, Izdatelstvo Nedra, Moscow (in Russian). [Сирык И.М. 1970. Грязевыевулканы / / Геология
СССР. Т. 33 / под реА. В.Н. Верещагина и Ю.В. Ковтуновича. Москва: Недра, 1970. С. 355-368].

Ting, T.M. \& A.D. Poulsen 2009. Understorey vegetation at two mud volcanoes in north-east Borneo. Journal of Tropical Forest Science 21(3):198-209.

Tsuyuzaki, S. 1991. Species turnover and diversity during early stages of vegetation recovery on the volcano Usu, northern Japan. Journal of Vegetation Science 2(3):301-306.

Tsuyuzaki, S. 2009. Causes of plant community divergence in the early stages of volcanic succession. Journal of $V e g$ etation Science 20(5):959-969.

Tsuyuzaki, S. \& A. Hase 2005. Plant community dynamics on the volcano Mount Koma, northern Japan, after the 1996 eruption. Folia Geobotanica 40(4):319-330.

Ueda, M. 1938. The Magutan mud volcano. SakhKNII AN SSSR, Yuzhno-Sakhalinsk, 40 pp. (in Russian and Japanese).[Уэда M. 1938. Грязевой вулкан Магунтан. Южно-Сахалинск: СахКНИИ АН СССР, 40 с.].

Walker, L.R. \& R. del Moral 2003. Primary succession and ecosystem rehabilitation. Cambridge University Press, New York, $456 \mathrm{pp}$.

Walker, L.R., J. Walker \& R.J. Hobbs 2007. Linking Restoration and ecological succession. Springer, New York, $188 \mathrm{p}$.

Walker, L.R., D.A. Wardle, R.D. Bardget \& B.D. Clarkson 2010. The use of chronosequences in studies of ecological succession and soil development. Journal of Ecology 98(4):725-736.

Zobel, M., E. van der Maarel \& C. Dupré 1998. Species pool: the concept, its determination and significance for community restoration. Applied Vegetation Science 1(1):55-66. 